УДК 338.436.33:332.133.6

JEL Classification: Q1; Q5; B41

DOI: https://doi.org/10.32317/2221-1055.202001121

E.V. GUSAKOV, candidate of economic sciences, associate professor (docent)

\title{
Theory and methodology of cluster development of agro-industrial complex
}

The purpose of the article is to substantiate the theory and methodology of cluster development of the agro-industrial complex (AIC).

Research methods. The following scientific methods were used in the work: monographic, systemic and comparative analysis, abstract logical and normative.

Research results. Ten basic principles of the development and implementation of cluster policy in relation to the AIC are formulated: the principle of scientific support, the principle of consistency in the AIC organization, the principle of the complexity of the AIC building, the principle of the prospects of the AIC development, etc.

A number of limitations have been identified that impede the spread of cluster structures in the AIC sphere (lack of special legislation, lack of long-term positive practice, lack of systematic scientific research, etc.), as well as a number of factors that give the right to quickly deploy cluster processes and to level constraint factors (extensive historical experience in the formation of various forms of cooperation and integration, the developed principles of the theory and practice of creating food and grocery companies in latest time, etc.). Because of this, positive factors being used can significantly prevail over the restraining factors and consistently level them. Due to this, evaluation criteria and indicators for the creation of competitive cluster associations in the AIC have been worked out. I

Elements of scientific novelty. A new definition of the AIC clustering as a megacluster system is formulated, the scientific novelty of which is that one formulation reflects targeted cooperation and subjects integration, a multilevel and multi-aspect participant composition, aiming on the observance of subjects economic interests, the need for rational resources use, the possibility of prompt resources redistribution, focus on strategic competitiveness.

Practical significance. The cluster policy in relation to the AIC sphere has certain stages, where each redistribution has its own characteristics of cooperation and integration. For this, an appropriate roadmap for the sequence of clustering steps has been developed. In order to develop the roadmap, the effects of the functioning of cluster systems in the AIC (attraction of investments, sustainable development of the technical and technological base, optimization of the ratio of different resource types, etc.) were worked out and based on them possible indicators were formulated to ensure an adequate assessment of the state and results of the AIC clustering. Tabl.: 1. Figs.: 1. Refs.: 11.

Keywords: agro-industrial complex; a cluster; balanced resource provision; consistency of organization; infrastructure optimality; cluster policy roadmap.

Gusakov Egor Vladimirovich - candidate of economic sciences, associate professor (docent), head of the sector of cooperation, Institute of System Researches in the Agro-Industrial Complex of the NAS of Belarus (103, Kazintsa st., Minsk, Belarus)

E-mail: Ego-6@mail.ru

Scientific problem. The growing scientific and practical interest in substantiating the methodology of innovative structural transformations of agro-industrial economic systems, as well as in the creation and development of viable and effective cluster structures, with insufficient elaboration of many methodological and methodical issues in the cluster organization of the agro-industrial complex, has determined the relevance of the problems under consideration.

C E.V. Gusakov, 2020
The ongoing research is carried out in the framework of the State scientific and technical program "Agropromkompleks-2020", as well as the State program of scientific research "Quality and efficiency of agroindustrial production" for 2016-2020.

Analysis of recent research and publications. The works of many authors are devoted to the study of the theoretical and methodological basis of the formation and functioning of cluster formations and their management, among which $\mathrm{M}$. Porter, the founder of cluster organization, occupies the most prominent place. Also, foreign researchers such as 
A. Weber, G. Schmitz [9], P. Swann, M. Prevezer, S. Rosenfeld, E. Fezer, D. Stout, W. Elsner, studied the problems of clustering economic space and business entities, T. Rolandt, P. Hertog [8], J. Simmy, J. Senny, T. Egan, S. Crouch, G. Farrell and others. Issues related to the formation of territorial and regional clusters are comprehensively considered in the writings of such foreign scientists as P. Krugman, M. Enright, E. Bergman, L. van den Berg, E. Brown, W. van Winden, J. Leiten, I. Limpens, J. Wally and others. A significant contribution to the development of scientific knowledge on improving the efficiency and competitiveness of economic structures through cooperation, integration, and clustering was made by such Russian researchers as I.G. Ushachev [10], Yu.V. Vertakova, G.R. Khasaev, L.A. Alexandrova [1], O.V. Kostenko, K.A. Vasiliev, V.V. Pechatkin, V.V. Demichev, A.E. Shamin, V.V. Prokhorova, G.M. Kvon, T.V. Ivanova, S.V. Gasparyan, A.A. Dibirov, I.A. Minakov, N.P. Shilova, M.M. Tryachtsin, I.N. Sycheva, and others. A great contribution to the study of the problems of creating and functioning of effective cooperative integration and cluster associations in the agro-industrial complex under new conditions was made by Belarusian scientists, among them V.G. Gusakov [3], A.P. Shpak, M.I. Zapolsky, V.I. Belsky, A.V. Pilipuk. Nevertheless, the issues of the formation and development of cluster structures, their integration into domestic agrifood practice, as well as adaptation to the national macroeconomics, taking into account the characteristic features of its functioning in the new conditions, still remain unexplored.

The purpose of the article is to substantiate the theory and methodology of cluster development of the agro-industrial complex (AIC).

Research results. In modern conditions, problems associated with the structural and institutional policies of the agro-industrial complex have become aggravated. or scientists and practitioners, the need for crosscutting structural improvement of the agroindustrial complex, acceleration of innovative and technological transformations, increasing the sustainability of the agricultural economy, including domestic and foreign economic challenges (commercialization of interest rates on loans, reduction of state support, Belarus's entry into the EAEU with the adoption of several restricting obligations for national producers, etc.) have become obvious.

At the same time, the elaboration and implementation of measures to formulate a new structural agrarian policy encounter significant difficulties - disunity of agro-industrial enterprises and regions, heterogeneity of regions and socio-economic space, which, despite all attempts of centralized budget subsidies, smoothing the differentiation of administrative regions and large business entities (the AIC enterprises) remains significant. Under these conditions, overcoming economic contradictions and giving the necessary impetus to the development of agro-industrial production is possible not only on the basis of leveling the existing economic differentiation but primarily in connection with the use of organizational, economic and managerial approaches based on the transformation of the domestic agro-industrial complex into crosscutting agro-industrial agglomeration, on the formation and priority development of territorially-spatial points of economic growth. The methodological basis of such the AIC development tool is the cooperative-integrative or cluster approach.

The study shows that the tools of the innovative cluster approach make it possible to balance the producers and the state interests, smooth out the negative displays of market competition and conjuncture, diversify the risks of the AIC socio-economic development, make the most of the potential of selfmanagement and self-development of enterprises and their associations with measures of their centralized regulation and economic providing. Accordingly, the agrarian policy of the country, using the cluster approach, acquires a comprehensive balanced nature, gets an opportunity to include mechanisms of innovativeness and revitalization, owning the maximum multiplying effect. It is based on the proportional relationship of cluster organization measures with the program and regulatory documents of the republican and regional level, which allows increasing the degree of the agricultural economy stability, the development of interstructural (intercluster) relations, stimulation of innovation and investment activity of business entities, etc. In addition, the advantage of cluster policy is the ability to combine the accomplishments of the macroeconomic and microeconomic components of economic development in one 
mechanism, including territorial and socioeconomic aspects. The main goal of cluster policy in relation to the agro-industrial complex is to ensure sustainable development and increase the competitiveness of the economy through the formation and strengthening of integration relations between business entities of different industries and activities that mediate the effective use of scientific, innovative, technical, technological, industrial, financial, economic, managerial and personnel potentials [1-11]. Based on this, we formulated the definition of the clustering of the agro-industrial complex as a megacluster system. This is cross-cutting targeted cooperation and integration of business entities (both voluntary and at the initiative of management bodies) vertically (production, processing, marketing) and horizontally (territorial and regional location), having an interest in the dynamic development of production and marketing infrastructure and increasing total income based on the rational use of production, technical, technological and natural resources and having the ability to quickly rearrange resources to key areas and activities based on the market conjuncture and to improve the current and strategic competitiveness.

As you can see, the formulated definition of agro-industrial complex clustering has an undeniable scientific novelty. So, in one definition are reflected: targeted end-to-end cooperation and entities integration, multi-level and multi-aspect participants composition, focus on the implementation of economic interests of entities, the need for rational use of resources, the possibility of operative redistributing resources, focus on strategic competitiveness. Therefore, its use allows you to have a clear comprehensive understanding of the substance and nature of the cluster organization in such a large sector of the economy as the agro-industrial complex.

To further that, we have formulated the principles for the elaboration and implementation of cluster policy in relation to the AIC. Their main content is as follows:

the principle of AIC scientific support and the scientific nature of cluster policy. The agro-industrial complex is a sector with great specificity. The natural factor has a considerable influence here: one has to work with living organisms in crop production and animal husbandry, there is a large spatial dispersion of production, etc. Therefore, the entire organization of the agro-industrial complex, its strategy and policy must have comprehensive scientific basis;

- the principle of systemic of the AIC organization and the cluster policy construction. Systemic implies the necessity to consider the diverse management factors, the interconnection, and interdependence of various sectors and fields, a causal relationship of factors and results, the final criterion of which is optimality;

- the principle of the complexity of the AIC building and the cluster policy formation. Complexity follows from the very essence of the AIC organization, which is a complex infrastructure formation both horizontally and vertically. It is impossible to develop individual industries, sectors, and enterprises of the AIC, beyond regardless of others. Everything is presented in a complex, from here it is necessary to build end-to-end technological chains from the raw material production to its processing and finished products marketing, including the resources supply;

- the principle of promising of the AIC development and the strategic orientation of cluster policy. Any AIC development should be directed towards the future. In this regard, short-term and long-term plans and forecasts, strategies, and concepts containing quantitative and qualitative criteria and scenarios should be developed;

the principle of the AIC optimality infrastructure and the balance of the interests of cluster policy participants. The composition of the main and auxiliary branches of the agro-industrial complex should be strictly balanced and complemented, it is also important to maintain the approximately equal interest of various cluster members in the results of both their activities and the entire cluster association;

- the principle of the strong motivation of participants in a cluster organization. It is known that at the base is of any production success are mechanisms of strong motivation, without which the sustainable AIC development is impossible. This involves the elaboration of such effective mechanisms at all levels of the cluster policy functioning;

- the principle of balanced resource provision, which means that any production must be based on a variety of resources - material, financial, labor, etc. $\mathrm{n}$ this regard, in order to achieve production targets, it is important to have a balance both the resource composition 
between their types (internal resource balancing) and between the general resource composition and calculated production volumes (balance of the "cost-benefit" system);

- the principle of the main link in the AIC development and cluster policy. This is one of the main principles that indicates that there can and should be major (for example, plant growing and animal husbandry branches) and auxiliary (supply and service spheres) activities in the AIC. When creating cluster and cooperative integration associations, it is also important to have integrating structures or socalled integrator enterprises;

the principle of the innovative orientation of the AIC results and their cluster organizations. So, the innovativeness of activities allows maintaining the necessary level of competitiveness and providing additional incomes;

the principle of monitoring processes and the AIC development results and its cluster structures. The principle involves the implementation of a systematic analysis of economic activity, the need for comparative assessments, the objectivity of conclusions and proposals, on the basis of which periodic monitoring processes and results is organized.

Thus, we have proposed ten basic principles for the implementation of cluster policy in the AIC sphere. Their combination with regard to clustering processes has developed for the first time. The novelty consists both in the general selection of the principles and in their interpretation with respect to cluster policy. It is important to emphasize that these are the principles of the creation and functioning of precisely cluster associations, although the principles of the development of commodity production are found in studies of other authors.

The study shows that the development of cooperative integration associations and clusters is formalized in cluster policy. Cluster policy as a tool for ensuring the competitiveness of economic development has become widespread in the world. As a result, two main cluster policy models were formed: 1) dirigisme, where government policy plays an important role (Sweden, France, Finland) and 2) liberal, in which the cluster is seen as a market mechanism. The state here creates only legal conditions for their normal functioning (the USA, UK, Canada). As part of these models, cluster policy distinguishes depending on the place and role of the state, the composition of participants and structure, types of products, conditions of territorial distribution, level and stages of development. At the same time, an in-depth analysis confirms that it is more appropriate to implement a mixed model of cluster policy that can combine the interests of the state and business based on a predetermined infrastructure and cooperative integration interactions.

Taking into account the need to develop the basics of cluster policy for the economy of the Republic of Belarus, we have established that cluster policy in relation to the agro-industrial complex has a certain phasing, where each redistribution has its own specifics of cooperation and integration. Such a step sequence or a kind of roadmap is presented in Figure.

As can be seen from the figure, the crosscutting procedure for cluster structures creating in the AIC includes ten consecutive steps from the idea emergence and initiative expression to the focus on obtaining products of expected quality and evaluating the cluster activity according to the criteria of competitiveness and consumer satisfaction.

The presented roadmap has a scientific novelty, which consists not only in the development of a particular technology for the creation and establishment of the effective functioning of the cluster and cooperative integration associations but also in the formulation of each stage content. For example, the first stage content (expression of an idea and initiative) involves a hypothetical study of the advantages and creation conditions, an idea discussion with potential participants and an initiative expression as necessary and in order of organization; the tenth stage content (activity assessment), as fundamental, requires a systematic assessment of the cluster activity according to a number of criteria - the range and quality of products, satisfaction of consumer demand, and the level of competitiveness.

Therefore, compliance with the conditions of each stage and the roadmap as a whole makes it possible to create cluster associations in a logical sequence, to eliminate possible losses of time, labor and attracted resources. The content of the roadmap stages reveals the main meaning of organizational activity and indicates to business entities that have set the task of cooperation, on what issues to concentrate efforts. 
Stage 1. The idea of creating a cluster.

The main content of the stage: a hypothetical study of the advantages and conditions of creation, discussion of the idea with potential participants, expression of the organization's initiative

$$
\prod
$$

Stage 2. Determining the goals and objectives of the implementation of ideas and initiatives for the organization. The main content of the stage: conducting a SWOT analysis to determine the strengths and weaknesses of organization and functioning, formulating on their basis the main goal and related goals and objectives

Stage 3: a) Definition of the enterprise-integrator (under the implementation of the dirigisme model). the liberal model).

b) Determining the conditions for equal interaction of potential participants (under the implementation of

c) Organization of direct interaction between government bodies and potential participants in a cluster organization (under the implementation of the mixed model).

The main content of the stage: analysis of the existing conditions and possibilities of creating and select a specific model for the implementation of the initiative, adoption of the model by all possible parties and potential cluster members

Stage 4. Construction of the organizational and economic structure of the cluster.

The main content of the stage: final determination of the participant number in the cluster, including government bodies, adoption the order of entry, determination of the order of participant interaction, approval of the conditions for participant interaction with the main integrator company or another company that will be entrusted with performing conducting functions, the formation of general cluster services - managerial, economic marketing and others

Stage 5. Development of cluster specialization and the formation of one or more core activities.

The main content of the stage: the distribution of functions, rights, and responsibilities between cluster members, building the value chain of product promotion, determining auxiliary, related and additional types of production or work for the effective functioning of the main production and the cluster as a whole

Stage 6. Theoretical and economic grounding and development of a business plan for the cluster development (annual or long-term).

The main content of the stage: selection, coordination, and approval of quantitative and qualitative indicators of the cluster functioning, calculations of production volumes and sales revenue, adoption of the procedure for redistributing the economic result between the participants

Stage 7: a) Development and adoption of incentive mechanisms for cluster members to work as part of an integrated structure.

b) Development and adoption of mechanisms for effective motivation for the growth of production and marketing, as well as labor productivity growth.

The main content of the stage: mechanisms for stimulating the cluster organization and motivation of labor and production are the most important in the system of establishing the effective functioning of the cluster organization. Therefore, a careful selection of methods and functions for the formation of these mechanisms is necessary, so that they meet the target interests of all participants

Stage 8. Development of mechanisms to maintain high cluster competitiveness.

The main content of the stage: the formation of investments in innovation, the definition of the main link (core) and the resource concentration in key areas of functioning, maintaining a balance between the main and auxiliary production

Stage 9. Formation of the necessary and sufficient technical and technological base of the cluster.

The main content of the stage: the formation of balanced resource potential, an adequate technical and technological level, proportional complementarity of all types of resources - technical, financial, labor, etc., the achievement of the resources target payback

Stage 10: a) The cluster's focus on obtaining products in the assortment of the highest quality.

b) The focus of production on market sales and the satisfaction of specific consumer demand.

c) Focus on obtaining the latest types of products that can withstand competition.

d) Evaluation of the cluster's activity according to the quality criteria, competitiveness and market demand satisfaction.

The main content of the stage: this is the core stage of the cluster functioning, depending on its outcome, the conditions of the organization at all previous stages can be adjusted. It shows intermediate and final effectiveness and potential ability to function stably in harsh market conditions. Therefore, both the assortment and the quality of products, as consumer demand, and the criteria for satisfying it, both the competitiveness potential and actual competitiveness should be indispensable indicators of permanent assessment to maintain the real stability of the cluster organization

\section{Figure. Roadmap of cluster policy formation}

Source: Elaborated by author based on own research. 
The study shows that the main effects of the cluster systems functioning in the AIC are:

- investment attractiveness (of all forms public, private, foreign, etc.) in the sphere of the "new" economy;

- sustainable development of the technical and technological base and resource potential, the introduction of the latest technologies, the use of scientific achievements and the expansion of the practice of scientific and innovative activities, the mastering of competitive types of production;

optimization of the ratio of various resources, including employment in all the cluster divisions;

- targeted increase in production and sales volumes, the maximum realization of export potential;

- steady growth of gross domestic product and labor productivity, the use of the most effective motivation systems for labor and production;

- the concentration of the most qualified personnel, the rapid development of the competencies of managers and specialists employed in various sectors of the cluster.

Based on this, we have worked out possible indicators to ensure an objective assessment of the state and results of the AIC clustering, and we propose the following composition:

1. The volume of the entire cluster products, including innovative (for the Belarusian and foreign markets);

2. Types of innovative products supplied by the cluster;

3. The share of value-added from the production of innovative products in the total amount of value created;

4. The level of return on investment in the innovative products formation compared with the return on investment for all the cluster products;

5. The number of created jobs in the innovative part of production; employment optimization indicator in all cluster structures;

6 . The level of labor productivity in the innovative part of production compared with labor productivity in the entire cluster;

7. The growth rate of revenue from the sale of innovative products compared with the dynamics of the total cluster revenue;

8. The amount of wages per employee in the innovative part of production compared with the total wage in the cluster and the total wage in the AIC;
9. The cluster share in terms of the main production and financial indicators in the entire agro-industrial infrastructure complex;

10. Sizes and geography of export of innovative competitive products.

Present indicators, as the comparative analysis confirms, correspond to the goals, objectives, and specifics of the organization and functioning of the latest cluster formations in the AIC, as well as the innovative development of the AIC itself.

At the same time, an analysis of the cluster structures development in the Republic of Belarus allows us to identify a number of restrictions and contradictions that impede their spread in the AIC sphere. First of all, we have established that the following constraint factors take place in the agrarian complex:

a) lack of special legislation giving the right to priority development of cluster structures and innovative cooperative integration associations;

b) lack of long-term positive practice for the development of cluster structures and cooperative integration associations in sectors and spheres and in the country economy as a whole;

c) the lack of systematic research and development of scientists which could become the basis for the creation of adequate cluster structures in the AIC;

d) the weak innovative potential of agroindustrial production and the lack of clearly expressed interest of business entities in cross-cutting cooperation and integration and the cluster structures creation;

e) the gap between the domestic agroindustrial production and innovation processes taking place in world agriculture and orientation towards the enclave nature of the AIC development;

f) the fragmentation and isolation of existing agro-industrial enterprises, aspiring to create within their borders all the necessary infrastructure for market management and contenting with low added value and low innovation rates;

g) the insufficient propaganda of innovatively active enterprises and associations; the lack of information on the development of the most market-successful organizations; low trust level in scientific and innovative management methods;

h) the institutional imbalance in the agroeconomic system (the lack of mobile consul- 
ting and service companies, qualified economic and marketing services); the lack of special training and retraining of personnel on clusterization issues and the creation of cooperative integration associations in the educational system.

However, along with this, there are positive factors that give the right to deploy cluster processes in the economy and level the constraint factors. We have revealed that the stimulating factors are:

a) existing of extensive historical experience in the formation and development of various forms of cooperation and integration and the creation on their basis of various territorial-production complexes and cooperative-integration structures, such as republican, regional and district agro-industrial associations (regional agro-industrial association (RAIA), district agro-industrial association (DAIA), inter-farm and inter-industry production associations (trusts, unions, associations), etc.;

b) the elaborated foundations of the theory and practice of creating food companies in recent times, which demonstrate the clear advantages of cooperation and integration in the AIC (dairy companies, meat associations, tribal agro-industrial enterprises, etc.);

c) a sufficiently high level of agricultural and economic science, which is able to develop the necessary organizational, economic and legal mechanisms for the formation of effective cluster structures in the AIC and the transformation of the $\mathrm{AIC}$ into a megacluster;

d) the predominance in the practice of agro-industrial production relatively large agro-industrial enterprises and associations that have large production technologies and are examples of further cooperation and integration (by the way, in the AIC of Belarus has been actively continuing the process of enterprises enlargement and the creation of various associations based on them that prove the advantages of scale effect);

e) the tasks were set to increase production and sales, including export, to increase economic efficiency (it is necessary to withstand competition with leading world producers and suppliers); a strategy for expanding the export sales geography was put forward; the urgent goal is to constantly improve the quality and consumer value of finished food under a diverse consumer demand.

The analysis confirms that there are many other factors that testify in favor of clustering, cooperation, and integration. For example, a country has achieved full food security through domestic production, a unified economic policy and a corresponding strong state power have been acting, a balanced specialization has developed across the country, and there is a well-developed system for the agricultural production distribution, as well as all the necessary infrastructure - production, marketing, processing, procurement, etc. By virtue of this, positive factors when they are involved can significantly prevail over constraint factors and consistently level them.

At the end of this study, we developed evaluation criteria and indicators for the creation of competitive cluster associations in the AIC. The results of the study are presented in the Table.

Table. Criteria, indicators, and results of competitive clusters in the AIC

\begin{tabular}{|c|c|c|}
\hline $\begin{array}{c}\text { Cluster } \\
\text { competitiveness } \\
\text { criteria }\end{array}$ & $\begin{array}{l}\text { Performance indicators of } \\
\text { competitiveness criteria }\end{array}$ & $\begin{array}{l}\text { Characteristics and target results } \\
\text { of the organization and functioning } \\
\text { of competitive clusters }\end{array}$ \\
\hline $\begin{array}{l}\text { 1. Organization and } \\
\text { distribution scale }\end{array}$ & $\begin{array}{l}\text { 1. The composition of } \\
\text { participants in quantitative } \\
\text { terms. } \\
\text { 2. The composition of } \\
\text { participants in quality } \\
\text { characteristics. } \\
\text { 3. Coverage of the territory and } \\
\text { potential ability }\end{array}$ & $\begin{array}{l}\text { 1. The availability of material (technical, } \\
\text { technological, land) resources. } \\
\text { 2. The availability of financial resources. } \\
\text { 3. The availability of labor resources. } \\
\text { 4. The availability of organizational } \\
\text { and managerial competencies }\end{array}$ \\
\hline $\begin{array}{l}\text { 2. Level } \\
\text { of territorial } \\
\text { or spatial } \\
\text { concentration }\end{array}$ & $\begin{array}{l}\text { 1. The presence and size of the } \\
\text { integrator. } \\
\text { 2. The distance from } \\
\text { the integrator to other } \\
\text { participants (on average). } \\
\text { 3. The presence of auxiliary, } \\
\text { service and additional industries }\end{array}$ & $\begin{array}{l}\text { 1. The volume of production and sales from } \\
\text { the integrator. } \\
\text { 2. The presence and share of the main } \\
\text { production (or main product) in the total } \\
\text { production volume for all cluster structures. } \\
\text { 3. The volume of auxiliary, service } \\
\text { and additional production }\end{array}$ \\
\hline
\end{tabular}




\begin{tabular}{|l|l|l|}
\hline $\begin{array}{l}\text { 3. Realization } \\
\text { of potential } \\
\text { opportunities }\end{array}$ & $\begin{array}{l}\text { 1. The level of competitiveness. } \\
\text { 2. The pace of innovative } \\
\text { production. } \\
\text { 3. The level of product quality. } \\
\text { 4. The level of demand for } \\
\text { products }\end{array}$ & $\begin{array}{l}\text { 1. The level of competitiveness in the } \\
\text { presence of fixed and working capital. } \\
\text { 2. The level of competitiveness in terms of } \\
\text { technology modernization. } \\
\text { 3. The level of competitiveness in product } \\
\text { quality. } \\
\text { 4. The level of competitiveness in revenue } \\
\text { from sales and profits }\end{array}$ \\
\hline $\begin{array}{l}\text { 4. Value chain } \\
\text { formation }\end{array}$ & $\begin{array}{l}\text { 1. The size of the newly created } \\
\text { value. }\end{array}$ & $\begin{array}{l}\text { 2. The amount of value added. } \\
\text { 3. The amount of value added } \\
\text { from investment in innovation } \\
\text { involved in financing the newly created value. } \\
\text { 2. The amount of value added per one } \\
\text { enterprise - a cluster member (on average). } \\
\text { 3. The amount of value added per unit } \\
\text { of investment in innovation }\end{array}$ \\
\hline $\begin{array}{l}\text { 5. Functioning } \\
\text { strategy }\end{array}$ & $\begin{array}{l}\text { 1. The rate of growth and } \\
\text { development of the cluster. } \\
\text { 2. The share of investment in } \\
\text { development on the income } \\
\text { volume. } \\
\text { 3. The growth rate } \\
\text { (or reduction) of income from } \\
\text { investment in the development }\end{array}$ & $\begin{array}{l}\text { 1. Evaluation of the cluster functioning } \\
\text { strategy to increase its share in the regional } \\
\text { and republican markets. } \\
\text { 2. Assessment of competitive advantages } \\
\text { based on SWOT analysis. } \\
\text { 3. Assessment of the implementation of } \\
\text { promising (long-term) development plans }\end{array}$ \\
\hline
\end{tabular}

Source: Compiled by the author based on own research.

As shown in the table, to create clusters and ensure their necessary competitiveness in the AIC, it is necessary to develop and implement a number of criteria and indicators. Of course, the table summarizes the characteristics, in each case, when solving organization issues, it is necessary to take into account in more detail the goals of creation and the specifics of the activity, the level of specialization and production direction, economic, organizational and financial support, institutional content and marketing support. However, the results of the research presented in the table have an undeniable novelty. Its essence is that for the first time for the country AIC sphere, it was revealed that in order to achieve the competitiveness of clusters, five main criteria must be implemented: the scale of organization and distribution, the level of territorial or spatial concentration, the realization of potential opportunities, the value chain formation, and the consideration of a functioning strategy. To implement actual criteria, we have developed and proposed the most significant indicators, as well as given the characteristics and determined the target results of the organization and the functioning of competitive clusters.

Conclusions. Thus, the results of the studies make it possible, when forming cluster structures, to set direct tasks to achieve by them competitive advantages in obtaining high-quality and sought-after products, realizing potential opportunities and satisfying economic interests.

The advantage of the obtained scientific results, as opposed to the known ones, consists in systematically taking into account the latest trends and features of the AIC development, taking into account international experience, as well as taking into account the state goals and objectives for the accelerated development of the national AIC and its integration into the international agri-food space.

The obtained scientific results and further research in this direction can be used in the development of methodological, programmatic and regulatory documents governing the formation and development of innovative clusters at the macro-level (the level of the republic AIC and cross-cutting republican food and multibranched cooperative integrations and cluster associations), mezzo-level (level of the regional associations and organizations), micro-level (level of specific business entities, enterprises, and organizations). 


\section{Список бібліографічних посилань}

1. Александрова Л. А. Инновационный потенциал кластеризации аграрной экономики. Аграрный потенциал $в$ системе продовольственного обеспечения: теория и практика : материалы Всерос. науч.-практ. конф. (г. Ульяновск, 21-22 июня 2016 г.) / Ульян. гос. с.-х. акад. ; редкол.: В. А. Исайчев (гл. ред.), Н. Р. Александрова. Ульяновск, 2016. Ч. 1. С. 18-24.

2. Антонова Н. И. Агропромышленный кластер как инструмент развития отрасли. Продовольственная безопасность, импортозамещение и социально-экономические проблемы развития АПК : материалы междунар. науч.практ. конф. (г. Новосибирск, 9-10 июня 2016 г.) / Сиб. федер. науч. центр агробиотехнологий РАН [и др.]. Новосибирск, 2016. С. 78-82.

3. Гусаков В. Г. Механизмы конкурентоспособного развития АПК Беларуси в условиях функционирования ЕЭП и ЕврАзЭС / В. Г. Гусаков [и др.] ; Нац. акад. наук Беларуси, Ин-т систем. исслед. в АПК. Минск : Беларус. навука, 2014. $277 \mathrm{c}$.

4. Гусаков Е. Методологические подходы к построению и развитию АПК как мегакластера. Наука и инновации. 2019. № 10 (200). C. 26-31.

5. Пахомова А. А., Пахомов А. П. Перспективы создания агропродовольственного кластера Ростовской области. Никоновские чтения - 2011. Глобализация и аграрная экономика России: тенденции, возможные стратегии и риски / Рос. акад. с.-х. наук, Всерос. ин-т аграр. проблем и информатики, Рос. гос. аграр. ун-т - МСХА ; редкол.: И. Н. Буздалов [и др.]. Москва, 2011. С. 120-122.

6. Сердобинцев Д. В., Сорокина Л. В., Бекетова Е. С. Интеграция предприятий молочнопродуктового подкомплекса на основе кластерного подхода. Аграр. наука. 2012. № 8. C. 2-4.

7. Porter M. E. Clusters and the new economics of competition. Harvard Business Rev. 1998. Vol. 76, № 6. P. 77-90.

8. Roelandt T. J. A., Hertog D. Cluster analysis and cluster-based policy making in OECD countries: an introduction to the theme. Boosting innovation: the cluster approach / OECD. Paris, 1999. P. 9-26.

9. Schmitz H. On the clustering of small firms. IDC Bull. 1992. Vol. 23, № 3. P. 64-69.

10. Ushachyov I. G. A management system - the basis of the implementation of innovative development model of the Russian agro-industrial complex. Agro-industrial complex: economy. New Zealand Management. 2013. № 1. P. 13.

11. Van den Berg L., Braun E., Van Winden W. Growth clusters in European cities: an integral approach. Urban Studies. 2001. Vol. 38, № 1. P. 185-205.

\section{References}

1. Aleksandrova L. A. (2016). Innovacionnyj potencial klasterizacii agrarnoj jekonomiki. Agrarnyj potencial $v$ sisteme prodovol'stvennogo obespechenija: teorija i praktika [The innovative potential of agricultural economy clustering] : materialy Vseros. nauch.-prakt. konf., 21-22 ijunja 2016 g. / Ul'jan. gos. s.-h. akad. ; redkol.: V. A. Isajchev (gl. red.), N. R. Aleksandrova. Ul'janovsk, Ch. 1, pp. 18-24 [in Russian].

2. Antonova N. I. (2016). Agropromyshlennyj klaster kak instrument razvitija otrasli [Agro-industrial cluster as a tool for the development of the industry]. Prodovol'stvennaja bezopasnost', importozameshhenie i social'no-jekonomicheskie problemy razvitija APK : materialy mezhdunar. nauch.-prakt. konf. (Novosibirsk, 9-10 ijunja 2016 g.) / Sib. feder. nauch. centr agrobiotehnologij RAN [i dr.]. Novosibirsk, pp. 78-82 [in Russian].

3. Gusakov V. G. (2014). Mehanizmy konkurentosposobnogo razvitija APK Belarusi v uslovijah funkcionirovanija EJeP i EvrAzJeS [Mechanisms for the competitive development of AIC in Belarus under the conditions of the functioning of the EES and EurAsEC] / V. G. Gusakov [i dr.] ; Nac. akad. nauk Belarusi, In-t sistem. issled. v APK. Minsk : Belarus. navuka, 277 p. [in Russian].

4. Gusakov E. (2019). Metodologicheskie podhody k postroeniju i razvitiju APK kak megaklastera [Methodological approaches to the construction and development of the AIC as a megacluster]. Nauka $i$ innovacii. № 10 (200), pp. 26-31 [in Russian].

5. Pahomova A. A., Pahomov A. P. (2011). Perspektivy sozdanija agroprodovol'stvennogo klastera Rostovskoj oblasti [Prospects for the creation of an agri-food cluster of the Rostov region]. Nikonovskie chtenija - 2011. Globalizacija i agrarnaja jekonomika Rossii: tendencii, vozmozhnye strategii i riski / Ros. akad. s.-h. nauk, Vseros. in-t agrar. problem i informatiki, Ros. gos. agrar. un-t - MSHA ; redkol.: I. N. Buzdalov [i dr.]. Moskva, pp. 120-122 [in Russian].

6. Serdobincev D. V., Sorokina L. V., Beketova E. S. (2012). Integracija predprijatij molochnoproduktovogo podkompleksa na osnove klasternogo podhoda [Integration of dairy enterprises based on a cluster approach]. Agrar. Nauka, № 8, pp. 2-4 [in Russian].

7. Porter M. E. (1998). Clusters and the new economics of competition. Harvard Business Rev. 76, № 6, pp. 77-90 [in English].

8. Roelandt T. J. A., Hertog D. (1999). Cluster analysis and cluster-based policy making in OECD countries: an introduction to the theme. Boosting innovation: the cluster approach / OECD. - Paris, pp. 9-26 [in English].

9. Schmitz H. (1992). On the clustering of small firms. IDC Bull. Vol. 23, № 3, pp. 64-69 [in English].

10. Ushachyov I. G. (2013). A management system - the basis of the implementation of innovative development model of the Russian agro-industrial complex. Agro-industrial complex: economy. New Zealand Management. № 1, p. 13 [in English].

11. Van den Berg L., Braun E., Van Winden W. (2001). Growth clusters in European cities: an integral approach. Urban Studies. Vol. 38, № 1, pp. 185-205 [in English].

\section{Гусаков Є.В. Теорія і методологія кластерного розвитку АПК}

Мета статmі - обґрунтувати теоретичні засади та розкрити методологічні характеристики кластерного розвитку агропромислового комплексу.

Методика дослідження. Застосовувалися наступні наукові методи: монографічний, системного і порівняльного аналізу, абстрактно-логічний і нормативний.

Результати дослідження. Сформульовано десять основних принципів розробки та реалізації кластерної політики стосовно галузі АПК: принцип наукового забезпечення, принцип системності організації АПК, принцип комплексності побудови АПК, принцип перспективності розвитку АПК та ін.

Виявлено ряд обмежень, які перешкоджають поширенню у сфері АПК кластерних структур (відсутність спеціального законодавства, відсутність довгострокової позитивної практики, відсутність системних наукових досліджень і т. п.), а також ряд факторів, які дають право швидко розгортати кластерні процеси і нівелювати стримуючі фактори (наявність великого історичного досвіду формування різних форм кооперації та інтеграції, розроблено основи теорії та практики створення продовольчих і продуктових компаній в новітній час та ін.). Відповідно позитивні фактори при їх залученні можуть значно переважати над стримуючими і послідовно їх нівелювати. У контексті цього опрацьовано оціночні критерії та показники створення конкурентоспроможних кластерних об'єднань в АПК.

Елементи наукової новизни. Сформульовано нове визначення кластеризації АПК, як мегакластерної системи, наукова новизна якого полягає в тому, що в одному формулюванні відображені - цільова кооперація та інтеграція суб'єктів, багаторівневий і багатоаспектний склад учасників, націленість на дотримання економічних інтересів 
суб'єктів, необхідність раціонального використання ресурсів, можливість оперативного перерозподілу ресурсів, націленість на стратегічну конкурентоспроможність.

Практична значущість. Кластерна політика стосовно сфери АПК має певну етапність, де на кожному переділі мають місце свої особливості кооперації та інтеграції. Для цього розроблено відповідну дорожню карту послідовності етапів кластеризації. У розвиток дорожньої карти опрацьовано ефекти функціонування кластерних систем в АПК (залучення інвестицій, сталий розвиток техніко-технологічної бази, оптимізація співвідношення різних видів ресурсів та ін.). На підставі їх сформульовано можливі показники для забезпечення адекватної оцінки стану $i$ результатів кластеризації АПК. Табл.: 1. Рис.: 1. Бібліогр.: 11.

Ключові слова: агропромисловий комплекс; кластер; збалансоване ресурсне забезпечення; системність організації; оптимальність інфраструктури; дорожня карта кластерної політики.

Гусаков Єгор Володимирович - кандидат економічних наук, доцент, завідувач сектору кооперації, Державне підприємство «Інститут системних досліджень в АПК НАН Білорусі» (Республіка Білорусь, м. Мінськ, вул. Казінца, 103) E-mail: Ego-6@mail.ru

\section{Гусаков Е.В. Теория и методология кластерного развития АПК}

Цель статьи - обосновать теоретические основы и раскрыть методологические характеристики кластерного развития агропромышленного комплекса.

Методика исследования. Применялись следующие научные методы: монографический, системного и сравнительного анализа, абстрактно-логический и нормативный.

Результаты исследования. Сформулированы десять основных принципов разработки и реализации кластерной политики применительно к отрасли АПК: принцип научного обеспечения, принцип системности организации АПК, принцип комплексности построения АПК, принцип перспективности развития АПК и др.

Выявлен ряд ограничений, которые препятствуют распространению в сфере АПК кластерных структур (отсутствие специального законодательства, отсутствие долгосрочной позитивной практики, отсутствие системных научных исследований и m. n.), а также ряд факторов, которые дают право быстро разворачивать кластерные процессы и нивелировать сдерживающие факторы (наличие большого исторического опыта формирования различных форм кооперации и интеграции, разработанные основы теории и практики создания продовольственных и продуктовых компаний в новейшее время и пр.). Соответственно позитивные факторы при их задействовании могут значительно преобладать над сдерживающими и последовательно их нивелировать. В контексте этого проработаны оценочные критерии и показатели создания конкурентоспособных кластерных объединений в АПк.

Элементы научной новизны. Сформулировано новое определение кластеризации АПК, как мегакластерной системы, научная новизна которого состоит в том, что в одной формулировке отражены - целевая кооперация и интеграция субъектов, многоуровневый и многоаспектный состав участников, нацеленность на соблюдение экономических интересов субъектов, необходимость рационального использования ресурсов, возможность оперативного перераспределения ресурсов, нацеленность на стратегическую конкурентоспособность.

Практическая значимость. Кластерная политика применительно к сфере АПК имеет определенную этапность, где на каждом переделе имеют место свои особенности кооперации и интеграции. Для этого разработана соответствующая дорожная карта последовательности этапов кластеризации. В развитие дорожной карты проработаны эффекты функционирования кластерных систем в АПК (привлечение инвестиций, устойчивое развитие технико-технологической базы, оптимизачия соотношения различных видов ресурсов и пр.). На основе их сформулированы возможные показатели для обеспечения адекватной оценки состояния и результатов кластеризации АПК. Табл.: 1 Илл.: 1 Библиогр.: 11.

Ключевые слова: агропромышленный комплекс; кластер; сбалансированное ресурсное обеспечение; системность организации; оптимальность инфраструктуры; дорожная карта кластерной политики.

Гусаков Егор Владимирович - кандидат экономических наук, доцент, заведующий сектором кооперации, Государственное предприятие «Институт системных исследований в АПК НАН Беларуси» (Республика Беларусь, г. Минск, ул. Казинца, 103)

E-mail: Ego-6@mail.ru

The article has been received 26.12.2019

Revision: 02.01.2020

Бібліографічний опис для цитування:

Gusakov E. V. Theory and methodology of cluster development of agro-industrial complex. Економіка АПК. 2020. № 1. С. 121 - 130. https://doi.org/10.32317/2221-1055.202001121

Gusakov, E. V. (2020) Theory and methodology of cluster development of agro-industrial complex. Ekonomika APK, 1, pp. 121 - 130 [In English]. https://doi.org/10.32317/2221-1055.202001121 